
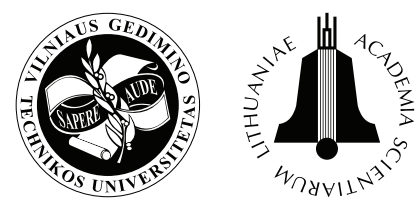

TRANSPORT

2010

25(1): 98-104

\title{
COMPARABLE ANALYSIS OF INFORMATION AND COMMUNICATION TECHNOLOGIES IN LITHUANIA AND FINLAND
}

\author{
Darius Bazaras ${ }^{1}$, Kristina Ledauskaité ${ }^{2}$, Ramūnas Palšaitis ${ }^{3}$ \\ Dept of Transport Management, Vilnius Gediminas Technical University, Plytinès g. 27, \\ LT-10105 Vilnius, Lithuania \\ E-mails: ${ }^{1}$ darius.bazaras@vgtu.lt; ${ }^{2}$ kristina.ledauskaite@vgtu.lt; ${ }^{3}$ trvadyba@vtgu.lt
}

Received 1 August 2009; accepted 1 February 2010

\begin{abstract}
Information exchange and making business transactions via the Internet and E-mail are very common nowadays. Thus, it is very important to investigate the use of applied Information and Communication Technologies (ICT) in activities undertaken by business and transport companies examining the levels the companies are making investments and to assess needs for a wider use of ICT in the logistics and transport companies. A number of authors in the Baltic States are analyzing ICT in separate business areas, for example transportation, warehousing, marketing, management etc. but none of those analyzes the use and development of ICT inside the company. The article describes the situation of using and developing ICT in the Baltic Sea Region and makes a comparison of Lithuanian and Finnish companies. Finland was chosen for benchmarking because research on ICT in the Baltic Sea Region (BSR) showed that the situation of using ICT in Lithuania and its neighborhood countries was similar.
\end{abstract}

Keywords: information, communication, technologies, industry, transport, logistics.

\section{Introduction}

Increasing traffic intensity unavoidably requires more rapid development and modernization of transport infrastructure which means not only larger investment but also better transport policy and an introduction of more advanced solutions such as promotion and deployment of intelligent transport systems (ITS) and services (Palšaitis 2007; Vasilis Vasiliauskas et al. 2008; Batarlienė and Baublys 2007; Jarašūniené 2007 and 2008; Jarašūnienè and Jakubauskas 2007; Burinskienè 2009; Szücs 2009; Yousefi and Fathy 2008; Daunoras et al. 2008; Gowri and Sivanandan 2008; Jakimavičius and Burinskienè 2009). Nowadays, intelligent transport systems are the ultimate product of information and communications technologies that is the hallmark of the digital age (Jarašūnienè 2006, 2007 and 2008). Many information technology (IT) tools are based on collecting, processing, integration and supply of information. The vision of ITS consists of the timely delivery of the available range of services to clients' business. At the same time, ITS service should guarantee the best business solutions and the lowest expenditure (Bazaras et al. 2007; Läikkö and Solakivi 2007).

The purpose of the article is to summarize the results of the survey on using and developing applied information and communication technologies (ICT) in the Baltic
Sea Region and to benchmark Lithuanian and Finnish companies. Research results at the macro level identified that enterprises had great demand for applying information and telecommunication technologies in business. It has been determined that companies providing modern information technologies (IT) to enterprises usually offer general-purpose application programs. In general, enterprises are ready to accept innovations. The qualification of staff members is relatively high, however, the need for improving their qualification still exists (Palšaitis and Ledauskaite 2008). The biggest perspective is seen in the production-related areas currently exclusively focused on cost-saving issues. However, research shows that companies are not that willing to invest into modern software and expenses for ICT are rather low and more focused on hardware than on personnel or software.

\section{An Overview on Using and Developing ICT in the Baltic Sea Region (BSR)}

Research on ICT in BSR (Fig. 1) shows that the distribution of companies by size is as follows: $62 \%$ - micro, $22 \%$ - small, $9 \%$ - medium and 7\% - large companies. The relative contradiction between the high level of BSR companies with the Internet access and employees having no access to it can be explained by the division of industrial sectors shown in Fig. 1. 


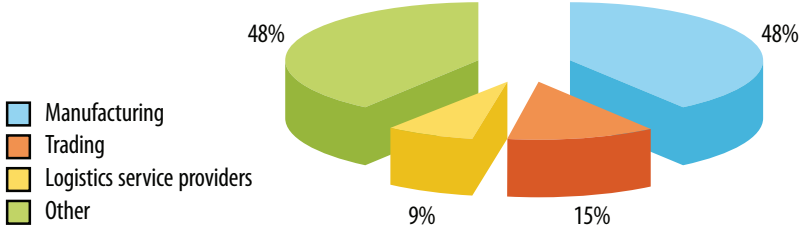

Fig. 1. The number of respondents according to the main industry in BSR

The usage rate of e-mail and the Internet is less than $75 \%$ but ICT is used at different degrees in various business areas. The two areas where ICT is widely implemented as support for daily activities are:

- accountancy;

- marketing and sale.

Expenditures of ICT as \% of gross domestic product (GDP) are quite different in BSR countries (Table 1).

ICT expenses (Fig. 2) cover:

- similar distribution for 3 types of expenses (modal values for all types of expenses were more than $2.5 \%$ );

- software expenses are expected to increase the most;

- nowadays, basic IT knowledge is common in the newer generations as a big number of people can use simple IT issues, however, specialists are needed for more complex issues.
Table 1. Comparative data on the proportion of ICT in the economic development of BS

\begin{tabular}{lccc}
\hline & $\begin{array}{c}\text { IT } \\
\text { expenditures/ } \\
\text { GDP in \% }\end{array}$ & $\begin{array}{c}\text { IT } \\
\text { expenditures } \\
\text { per capita in } \\
\text { EUR }\end{array}$ & $\begin{array}{c}\text { Number PCs } \\
\text { per 100 } \\
\text { population }\end{array}$ \\
\hline Estonia & 2.88 & 171 & - \\
\hline Latvia & 2.29 & 102 & - \\
\hline Lithuania & 1.66 & 86 & - \\
\hline Poland & 2.36 & 122 & 14 \\
\hline Germany & 2.93 & 797 & 43 \\
\hline Sweden & 3.85 & 1246 & 67 \\
\hline Finland & 3.27 & 989 & 50 \\
\hline
\end{tabular}

According to the regional use of the Internet and e-commerce, the obtained results are as follows:

- rural areas encounter problems with access to broadband Internet widely used at regional level;

- an increased use of company's web sides (about 90\%) and still high importance of personal contacts (about 82\%);

- high acceptance that e-commerce gives competitive advantage (Fig. 3) but none of the surveyed companies handles more than $60 \%$ of their business electronically.

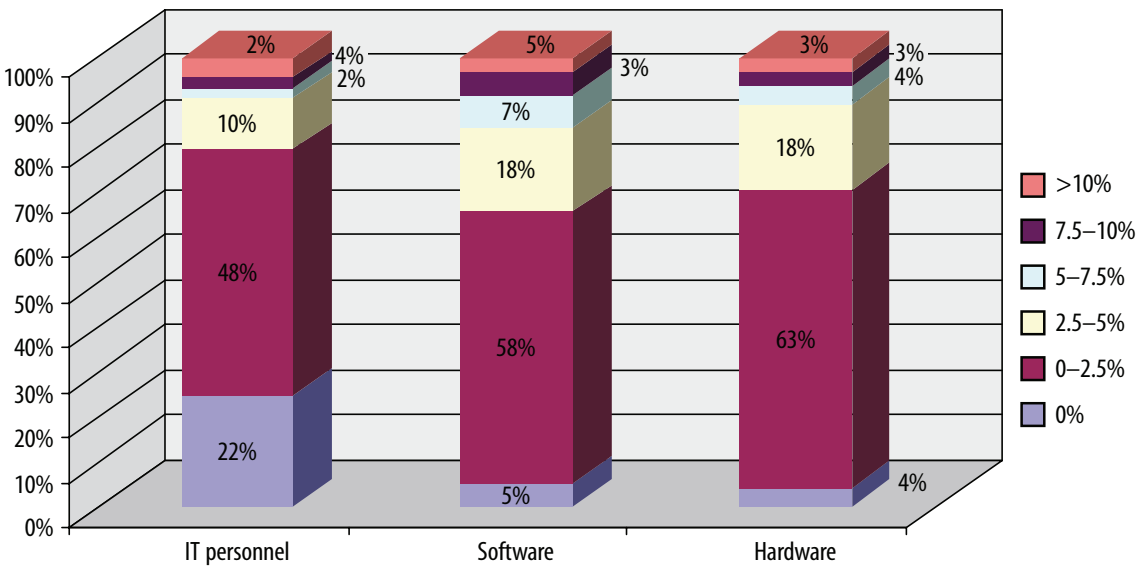

Fig. 2. ICT expenses as a percentage of company turnover in BSR

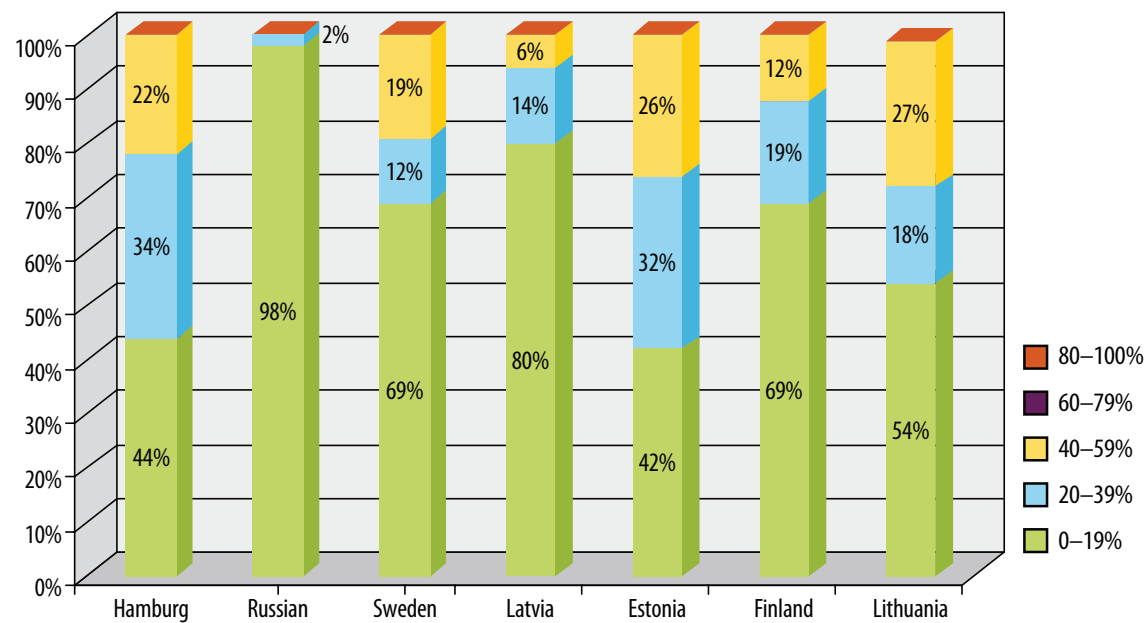

Fig. 3. The development of e-commerce with customers 
Also, the Internet is used interacting with public authorities and governmental organizations. In the majority of cases, the Internet is used for:

- obtaining general information (opening hours, contact persons, requirements for certain formalities etc.);

- downloading/requesting forms (tax return forms, regulations, licenses);

- completing forms online;

- making online payments.

The conducted research demonstrates that the survey revealed the following concerns and needs:

- a lack of qualified ICT personnel;

- the weak development of e-commerce due to the low awareness of its increasing importance;

- concerns about security issues;

- shortage of e-Government services.

These four steps will be taken into account as a basis for a comparative analysis between Lithuania and Finland. Finland was involved in the survey because the research results of using ICT in the Baltic Sea Region (BSR) showed that the situation of ICT in Lithuania and its neighborhood countries was similar.

\section{Comparison of the Situation on Using and Developing ICT in Lithuania and Finland}

A comparison of Lithuanian and Finnish companies has identified big differences between Lithuanian and Finnish companies (Table 2).

Table 2. Comparison of Lithuanian and Finnish companies considering size and industry

\begin{tabular}{|c|c|c|c|}
\hline & & Lithuania & Finland \\
\hline \multirow{4}{*}{$\begin{array}{l}\text { Comparison } \\
\text { according to } \\
\text { company's size }\end{array}$} & $\begin{array}{l}\text { Micro size } \\
\text { companies }\end{array}$ & $43 \%$ & $77 \%$ \\
\hline & $\begin{array}{l}\text { Small size } \\
\text { companies }\end{array}$ & $35 \%$ & $15 \%$ \\
\hline & $\begin{array}{l}\text { Medium size } \\
\text { companies }\end{array}$ & $15 \%$ & $5 \%$ \\
\hline & $\begin{array}{l}\text { Large size } \\
\text { companies }\end{array}$ & $7 \%$ & $3 \%$ \\
\hline \multirow{4}{*}{$\begin{array}{l}\text { Comparison } \\
\text { according to } \\
\text { industry profile }\end{array}$} & Manufacturing & $25 \%$ & $25 \%$ \\
\hline & Trading & $20 \%$ & $11 \%$ \\
\hline & $\begin{array}{l}\text { Logistic service } \\
\text { provides }\end{array}$ & $32 \%$ & $7 \%$ \\
\hline & Other & $23 \%$ & $57 \%$ \\
\hline
\end{tabular}

Investigation identified that the main business areas of using ICT in Lithuania companies were accountancy (nearly 95\%) and marketing/sales ( 75\%). The use of ICT in financing is over $85 \%$, whereas sourcing/supply makes more than $60 \%$. $65 \%$ of the companies use ICT means for production and planning and only more than $60 \%$ for human resources. Several companies deal with business areas having plans for a more intensive use of ICT. An increased use of ICT means in the areas of finance and accountancy is not surprising due to a high level of public services available via electronic channels in Lithuania, especially concerning reports on taxes and other financial/economical data compulsory to companies. Also, an increasing use of the Internet in Lithuania is a key factor in high level marketing/sales activities done with the support of ICT. Companies have realized the importance of being visible in the Internet. A low usage of new solutions in production (manufacturing) $(\sim 50 \%)$ and related areas is also very typical for Lithuanian manufacturing industry which is still based on subcontracting and low price advantage; however, the need for change is acknowledged. For the purposes of human resources, ICT management is used in $60 \%$ of the companies while for planning it makes $15 \%$. The number of companies preparing to start using ICT in some other areas is quite high which indicates that the companies are aware about ICT possibilities and are willing to use modern software.

However, the level of using ICT in different areas of business within the companies in Finland is not extremely high (Malmsten and Solakivi 2007). Such situation can be described by the fact that the biggest part of the participants of the survey was micro and small sized companies having neither financial resources nor needs to have as many functions in their applications as larger companies have. Roughly $5-10 \%$ of the companies are planning to use ICT in some new areas of business in the future. It is identified, that $66.1 \%$ of the companies participating in this survey are using ICT for accounting, $8.0 \%$ of those are planning to use ICT for accounting in the future and $25.8 \%$ are not using or going to use any. $67.6 \%$ of the companies use ICT for marketing and sales and $10.2 \%$ are planning to use ICT. $22.2 \%$ of the respondents are not using ICT in this business area at all. ICT can be used in the area of production for inventory control, costs and quality management. 50.6\% of the respondents use ICT in production operations and additional $4.6 \%$ are planning to use ICT. $44.8 \%$ of the companies are not going to use ICT for production management operations. This result is quite interesting because approximately $25 \%$ of the companies are pure manufacturing companies. Service based companies can also use ICT in their 'production' process, but in the sense of producing ordinary physical products, this result is warped. Production planning systems are used in $47.9 \%$ of the cases and $7.2 \%$ of those are planning to acquire one of these systems. $44.9 \%$ of the companies are not using ICT in production planning. $40.7 \%$ of the surveyed companies are applying ICT in logistics and/ or stock management systems for conducting business, 9.3\% are planning to use it and a half of the respondents are not going to use such a system.

The situation on using ICT in the segment of big and medium companies in Lithuania is better than that in Finland. This is due to the fact that in Lithuania, 30\% of the respondents claim to have an own IT department. The largest part of respondents ( 60\%) subcontracts ICT services and confirms that specialized ICT service providers can provide higher quality services. All of the above mentioned companies are concerned about differ- 
ent ICT related issues. Micro and small sized companies do not have resources for hiring several ICT specialists; they would rather have a 'contact person' for ICT related issues - an IT specialist or a person having more knowledge about IT. Companies using service providers are usually in a situation where they have acknowledged the need for a specialist but consider a separate qualified employee to be a waste of resource.

At the same time, about $16 \%$ of the surveyed Finnish companies have their own IT department. These are mostly medium and large companies. There are some small companies having their own IT department but the core business of those is either software development or providing IT services. An IT service provider is an alternative for having an individual IT department, especially when the core business is far away from IT but the systems are vital for the company to function. For example, advertising agencies, law firms and private doctor's offices need to have a server to run all their data but do not necessarily need fulltime to maintain the servers. Nearly $23 \%$ of the respondents use an IT service provider to maintain their systems and servers. Most of these companies also belong to the group of medium and large companies. Some small sized companies also use a service provider for their IT functions.

Research has revealed that there are quite many high professional IT companies that can provide its services for other companies in Lithuania. It is an open question about outcomes: from one point of view, it is a good idea because such situation allows the companies to develop specialization in their own activity field, from another point of view, in many cases, ICT products need a peculiar knowledge of manufacturing, trading or logistics activities. Looking at expenditures of ICT (\% of GDP), the situation in Finland is twice better than that in Lithuania, but comparing ICT expenses of the company turnover is fairly similar.

Many small Lithuanian companies exploit the knowledge of the younger generation generally capable of solving simpler ICT issues. Close to $75 \%$ of the companies spend less than $2.5 \%$ on personnel (Fig. 4) which shows that most of the companies have very small depart- ments or only one person employed in IT. The situation regarding software in Lithuania has progressed in recent years; however little expenditure for software is still an issue that comes from society's relative tolerance for illegal software (70-80\%). The companies also upgrade their software rarely and usually buy new software with new hardware when old computers are unusable. Very small sums of money are spent for special solutions developed according to personal company's needs and most of software among the micro-sized companies is for home-use.

In Finland, expenses for ICT in the responding companies are less than $2.5 \%$ of their turnover and this is the case occurring in about $80 \%$ of the companies (Fig. 5). It is clearly identified that the lowest expenses go to IT personnel and the same amount - to software and hardware. A big majority of the companies use less than $2.5 \%$ of their annual turnover of ICT. However, there are quite many law firms, advertisement agencies and accounting firms that use over $10 \%$ of their annual turnover of IT personnel, software and hardware. There are also ICT service providers in the group, which is expected, because these companies base their business on computer hardware and therefore use big amounts of money for hardware related acquisitions. Smaller companies sparsely need their own IT personnel and do not easily use services provided by IT consulting firms. In this case, the main reason is high costs of services provided by consulting firms and reduced need for IT related issues. $31.7 \%$ of the companies used $0-2.5 \%$ of their annual turnover for IT personnel, $5.3 \%$ of the companies used $2.55 \%$ of their annual turnover for IT personnel, $3.4 \%$ of the companies used $57.5 \%$ of their annual turnover for IT personnel, $1.6 \%$ of the companies used $7.5-10 \%$ of their annual turnover for IT personnel and $6.4 \%$ of the companies used over $10 \%$ of their annual turnover. These companies are mainly software companies and IT service providers. Own IT personnel mostly are needed for medium and large companies. Many of the companies that spend more than $10 \%$ of their turnover for hardware also spend over $10 \%$ for software. This group of companies clearly needs high performing computers and delicate software for their business.

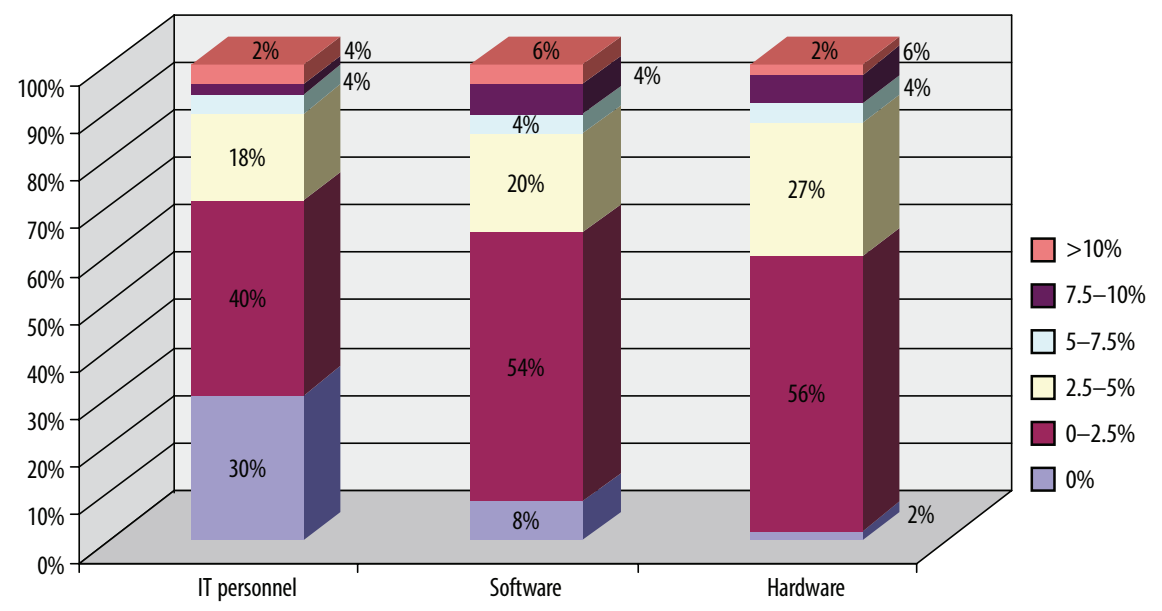

Fig. 4. ICT expenses as a percentage of company's turnover in Lithuania 


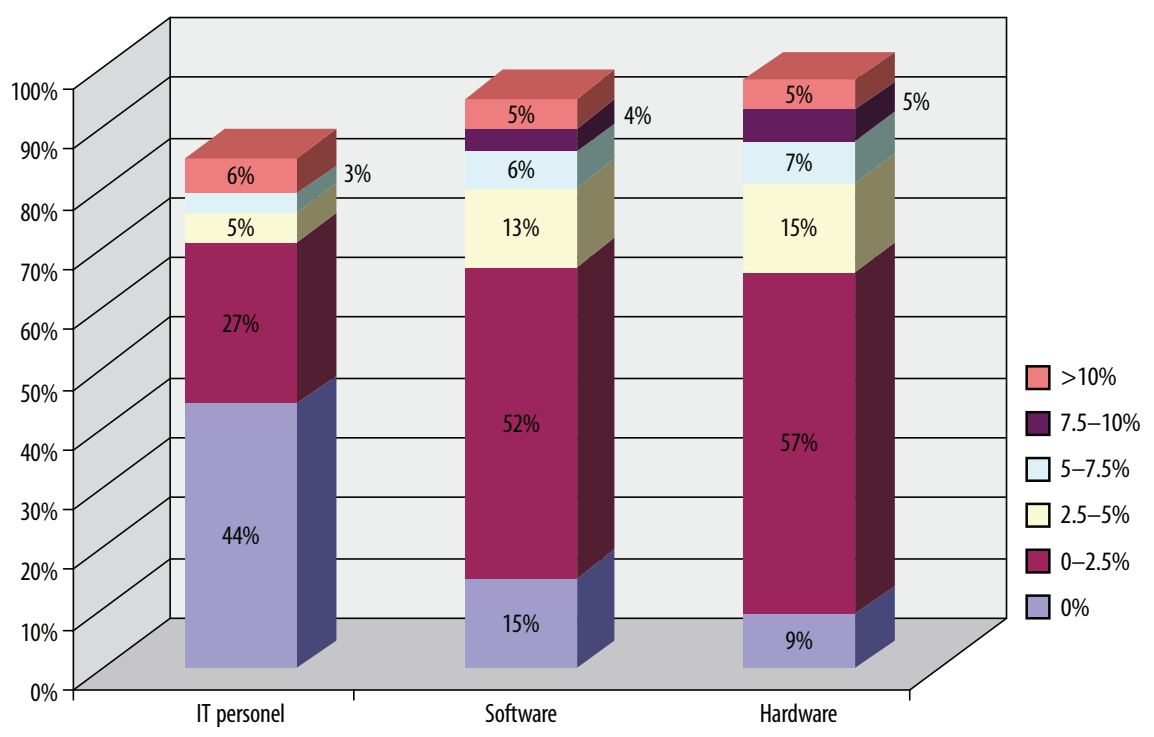

Fig. 5. ICT expenses as a percentage of company's turnover in Finland

The majority of companies in this group not only have ICT and telecommunication as core business but also service based companies like consultants, architects, lawyers and advertising agencies. Hardware performance is growing but radical changes are not to be expected in the near future. The prices of computers and peripherals have generally been decreasing in the past decade, whereas performance has increased in the same period. $67 \%$ of the respondents believe that their hardware costs are going to remain constant, $24.8 \%$ of those believe that the costs are going to increase and $8.2 \%$ - that the costs will decrease.

\section{E-commerce / E-business in Lithuania and Finland}

When electronic commerce was not developed, customers were not much interested in the costs of logistic operations associated with the supply and distribution of goods etc. Customers communicated with an enterprise via the middlemen of distribution channels involved in product delivery to a recipient. Electronic commerce allowed direct communication between customers and an enterprise avoiding the participation of middlemen (Palšaitis and Paliulis 2004).

The importance of E-mail communication among Lithuanian companies is very high and similar to using telephone/fax. Considering the level of using the Internet, the major part of companies has websites, including e-mail addresses. Traditional means like personal visits are simultaneously used in over a half of the companies. Regular post is used in approximately $40 \%$ of the companies. The share of company business is handled electronically. The companies see e-commerce to have a significant effect on several perspectives on doing business. The most important one is help with simplifying transactions and therefore speeding up the process. Not less important are the opportunities of reaching new customers or suppliers and improving service quality offered to the customers. The respondents do not agree that strongly about competitive advantages and profit- ability E-commerce creates, but still about 30\% has a positive attitude towards these perspectives.

A traditional way of conducting business in Finland is to make personal visits to customers and suppliers. $73 \%$ of the surveyed companies personally still visit their customers and suppliers. $85 \%$ of those use telephone and fax to communicate with their customers and suppliers. Telephone is the best media to explain any matter clearly and to get responses immediately. Email is used by $86 \%$ of the companies. It has replaced many traditional ways of making business and upgraded communication between companies to a new level.

\section{General Assessment of Using ICT}

For using the Internet, security is the only effective barrier for Lithuanian companies (Fig. 6). Expenses for development and data exchange are not seen as a problem. Surprisingly, neither is web surfing nor lost working time seen as problems concerning the use of the Internet. There are no obstacles seen on the use of e-commerce solutions. Payments and contractual issues are an area where the Internet providers or the Government has done the best job and where satisfaction is the highest one. In general, there are more barriers for using ICT. At the same level, we find at least four obstacles, including high expenditures for ICT, too many new versions and updates, supply of ICT not matching the needs and difficulties in recruiting qualified ICT personnel.

At the same time, security concerns for using the Internet seem to represent a major barrier for the companies in Finland (Fig. 7). Malicious software programs include a variety of threats such as spywares, viruses, worms, Trojan horses etc. Viruses are set to destroy data, use the computer for illegal actions, format the hard drive or make computer programs run improperly. Viruses typically spread from one user to another, i.e. via e-mail attachments. To hinder the possibility of getting viruses or hackers to computers, the companies should have antivirus software and firewalls installed to protect 


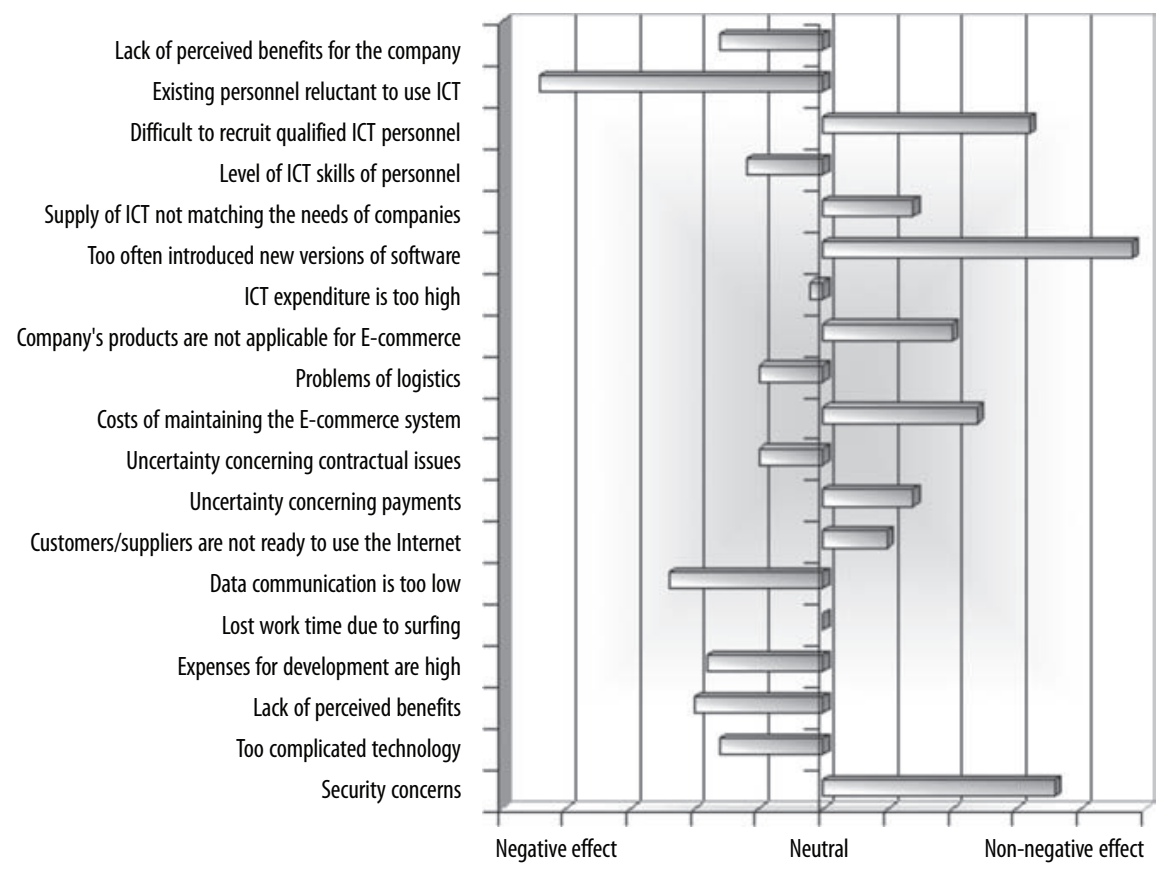

Fig. 6. The effect of different barriers on the use of the Internet, e-commerce and ICT in general (Lithuania)

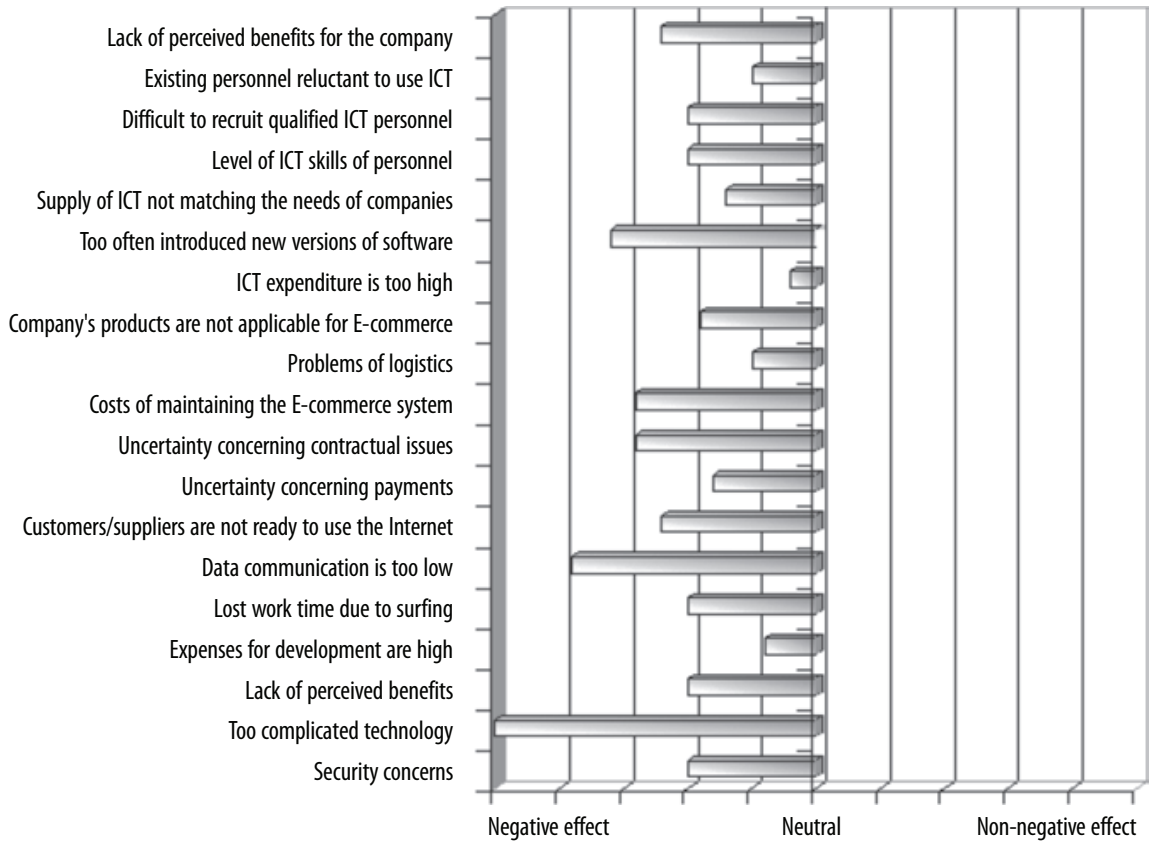

Fig. 7. The effect of different barriers on the use of the Internet, e-commerce and ICT in general (Finland)

data security. Some of the companies are clearly neglecting security concerns because they do not have these applications running in their systems.

In Finland, the effect of different barriers an the use of the Internet, ecommerce and ICT in general has more less than neutral which let us present findings that the current situation in Lithuania is much better.

\section{Conclusions}

1. The main business areas of using ICT in the companies of BSR, Lithuania and Finland are accountancy and marketing/sales; wider use of ICT in production related areas is expected in the future.

2. The main increase in costs is predicted for software. Increasing expenditure for software and hardware is at the same level but higher than that for IT personnel. Although password access control and virus protection applications are the most used measures for data security, password updates and usage are serious problems.

3. The importance of e-mail communication among Lithuanian companies is very high and similar to that 
of using telephone/fax. Considering the level of using the Internet, the majority of companies have websites, including e-mail addresses. Generally, in Finland, the meaning of e-commerce is recognized by the companies. E-commerce is growing; within the next three years, it is expected to grow about $10 \%$. The companies are using more and more electronic means to handle everyday business transactions.

4. Using the Internet, e-commerce and ICT in general is much better in Lithuania than that in Finland. Research showed that the survey revealed the following concerns and needs: lack of qualified ICT personnel, weak developments of e-commerce for general purposes due to the low awareness of its increasing importance, concerns about security issues, shortage of e-Government services.

\section{References}

Batarliene, N.; Baublys, A. 2007. Mobile solutions in road transport, Transport 22(1): 55-60.

Bazaras, D.; Palšaitis, R.; Solakivi, T. 2007. LogOn Baltic Regional Reports 24:2007. ICT Survey in Lithuania. Turku School of Economics. 52 p.

Burinskiené, M. 2009. New methodology for sustainable development towards sustainable transportation system, Technological and Economic Development of Economy 15(1): 5-9. doi:10.3846/1392-8619.2009.15.5-9

Daunoras, J.; Bagdonas, V.; Gargasas, V. 2008. City transport monitoring and routes optimal management system, Transport 23(2): 144-149. doi:10.3846/1648-4142.2008.23.144-149

Gowri, A.; Sivanandan, R. 2008. Evaluation of left turn channelization at a signalized intersection under heterogeneous traffic conditions, Transport 23(3): 221-229. doi:10.3846/1648-4142.2008.23.221-229

Jakimavičius, M.; Burinskienė, M. 2009. Assessment of Vilnius city development scenarios based on transport system modelling and multicriteria analysis, Journal of Civil Engineering and Management 15(4): 361-368. doi:10.3846/1392-3730.2009.15.361-368

Jarašūnienè, A. 2006. Analysis of possibilities and proposals of intelligent transport system (ITS) implementation in Lithuania, Transport 21(4): 245-251.

Jarašūnienè, A. 2007. Research into intelligent transport systems (ITS) technologies and efficiency, Transport 22(2): 61-67.

Jarašūnienè, A. 2008. Intelektualiosios transporto sistemos: monografija [Intelligent Transport Systems: Monograph]. Vilnius: Technika. 200 p. (in Lithuanian).

Jarašūnienè, A.; Jakubauskas, G. 2007. Improvement of road safety using passive and active intelligent vehicle safety systems, Transport 22(4): 284-289.

Läikkö, J.; Solakivi, T. 2007. LogOn Baltic Regional Reports 25:2007. ICT Survey in Southwest Finland. Turku School of Economics. 68 p.

Malmsten, J.; Solakivi, T. 2007. LogOn Baltic Regional Reports 53:2007. Regional Logistics \& ICT Profile: Southwest Finland. Turku School of Economics. 132 p.

Palšaitis, R. 2007. Transport infrastructure and information technologies development of the Lithuanian, in Proceedings of the 7th International Conference Reliability and Statistics in Transportation and Communication (Relstat'07), 24-27 October, Riga, Latvia, 33-36.
Palšaitis, R.; Ledauskaite, K. 2008. Determining the Effectiveness of Using Information Technologies in Lithuanian Transport Companies, in Proceedings of 5th International Conference 'Business and Management'2008'. 16-17 May 2008, Vilnius, 701-705.

Palšaitis, R.; Paliulis, N. 2004. Logistikos vadyba: Konsultacijos vadovui [Management of Logistics. Advices for Manager]. Vilnius: UAB „Verslo žinios“. 811 p. (in Lithuanian).

Szűcs, G. 2009. Developing co-operative transport system and route planning, Transport 24(1): 21-25. doi:10.3846/1648-4142.2009.24.21-25

Vasilis Vasiliauskas, A.; Jakubauskas, G.; Barysienè, J. 2008. Analysis of sustainable freight and passenger road transport development using ITS, Transport and Telecommunication 9(3): 4-8.

Yousefi, S.; Fathy, M. 2008. Metrics for performance evaluation of safety applications in vehicular ad hoc networks, Transport 23(4): 291-298. doi:10.3846/1648-4142.2008.23.291-298 